\title{
Effect of trophic status and sediment particle size on diversity and abundance of aquatic Oligochaeta (Annelida) in neotropical reservoirs
}

\author{
Yara Moretto $^{1,2 *}$, Nadson Ressyé Simões ${ }^{1}$, Evanilde Benedito ${ }^{1}$ and Janet Higuti ${ }^{1}$ \\ ${ }^{1}$ Graduate Studies Program in Ecology of Inland Aquatic Ecosystems, Maringá State University, Av. Colombo, 5790, PEA, Bloco \\ G90, CEP 87.020-900, Maringá, Paraná, Brazil \\ ${ }^{2}$ Laboratory of Ecology, Fishing and Ichthyology, Graduate Studies Program of Aquaculture and Sustainable Development. Federal \\ University of Paraná, Palotina Campus, Rua Pioneiro, 2153, Jd. Dallas, CEP 85950-000, Palotina, Paraná, Brazil
}

Received 21 April 2012; Accepted 13 March 2013

\begin{abstract}
The influence of the sediment grain size and the trophic status of the reservoirs on the composition, richness and biomass of Oligochaeta community was tested. Samples were taken from the littoral and profundal zones of 30 neotropical reservoirs from six different watersheds during two hydrological periods (dry and rainy seasons). The sample units were ordinated, with principal component analyses, according to differences in the sediment grain size, sample depth and dissolved oxygen. The results of a multiple response permutation procedure (MRPP) analysis revealed significant differences in species composition between littoral and profundal zones, trophic status (oligotrophic, mesotrophic and eutrophic) and different watersheds. The environment-species relationship was tested using redundancy analyses. In order to test which environmental variables, either granulometric or limnological, influenced the Oligochaeta community variability we used a partitioning procedure of inertia. Local variations, including reservoir zone and trophic status, were primarily influenced by differences in sediment type and depth. Significant differences in the total biomass between zones, trophic status, watershed and hydrological period were also demonstrated by a KruskalWallis or Mann-Whitney test. The most prevalent taxa were the cosmopolitan tubificids Bothrioneurum sp. and Branchiura sowerbyi, and the naidids Dero (Dero) digitata and Pristina breviseta, which are dependent on periphyton for food. Higher biomass values were recorded in mesotrophic reservoirs, due to increased nutrient availability and adequate dissolved oxygen supply. Our results indicate that the Oligochaete community structure is directly influenced by local environmental variation in neotropical reservoirs; and that the sediment grain size is the most important factor in determining the Oligochaete community structure.
\end{abstract}

Key words: Oligochaeta / richness / biomass / bioindicator / lentic water

\section{Introduction}

The classification of an environment according to its trophic status is an useful tool for managing lakes, and this can be estimated by simple measures of primary productivity, water transparency and nutrient concentration (Lind et al., 1993). These measures are important, because there is a link between nutrient supply, productivity and biological changes in aquatic ecosystems (Harper, 1992).

Alterations of the original environment, including changes to physical, chemical and biological aspects of the water body are the primary effects observed when reservoirs are created (Margalef, 1994; Matsumura-Tundisi et al., 2006). The principal consequences of these

\footnotetext{
*Corresponding author: yara.moretto@gmail.com
}

environmental changes are modifications to nutrient input and biological productivity, resulting in an environment with modified trophic status, generally classified as oligotrophic, mesotrophic and eutrophic.

Eutrophication can be a naturally occurring process in ageing lakes, but human activities can accelerate the rate at which nutrients enter aquatic ecosystems from the surrounding catchment areas (Harper, 1992; Menetrey et al., 2005). Following these changes, the eutrophication process is perhaps the most harmful effect resulting from reservoir construction, since it directly impacts the biological communities living in these environments (Rocha et al., 2006).

Benthic macroinvertebrates communities are related to nutrient concentrations and habitat conditions (Weijters et al., 2009; Friberg, 2010). Indeed, they have 
been used as bioindicators since their presence is indicative of water quality, particularly after alterations to the environment (Verdonschot, 1989). Consequently, there has been considerable research interest in biomass and production of benthic macroinvertebrates communities (Benke et al., 1999; Bagatini et al., 2007; Takahashi et al., 2008). They also play an important role in trophic interactions and energy flow through aquatic ecosystems (Benke et al., 1999).

Oligochaeta are one of the most abundant and diverse groups in benthic communities of rivers (Marchese and Ezcurra de Drago, 2006), streams (Alves and Lucca, 2000; Alves et al., 2006), lakes (Peralta et al., 2002) and reservoirs (Real and Prat, 1992; Dornfeld et al., 2006). The biomass of these organisms constitutes an important link in the trophic web, since they represent an important food source for fish and invertebrates (Lafont, 1987). Owing to their low mobility, long life cycle and direct contact with the substrate, aquatic worms have an intimate relationship with local environmental conditions (Alves and Lucca, 2000) and could be related mainly to the sediment type and conditions (Bletter et al., 2008, Martins et al., 2011). Since they are directly influenced by sediment characteristics, oligochaetes are one of the most informative taxonomic groups in studies of pollution (Chapman, 2001; Marchese and Ezcurra de Drago, 2006).

Here, we investigate the relevance of a number of local abiotic factors, related to water chemistry as well as to sediment type, zones and trophic levels; and regional factors such as hydrological periods and watersheds on the Oligochaeta community structure of 30 southern Brazilian reservoirs. We test the following hypotheses: (1) the composition, richness and abundance of Oligochaeta are affected by trophic status of the reservoirs, so we expect positive correlation between trophic status and biomass, and negative correlation with specific richness; (2) the composition, richness and abundance of Oligochaeta communities are determined by sediment grain size, so higher diversity and abundance are expected in reservoirs with predominance of larger sediment particles (see definition below).

\section{Material and methods}

\section{Study area}

We studied 30 neotropical reservoirs from six different watersheds: Piquiri, Ivaí, Tibagi, Iguaçu, Paranapanema and Litorânea. These locations are distributed across the Paraná State, from the Serra do Mar (sea mountain range and coastal region) to the northern regions, and include reservoirs located in the border between Paraná and São Paulo states (Julio et al., 2005) (Fig. 1). The studied reservoirs represent a range of environments with differing drainage areas, depths, morphometrics, ages and hydrological period. Furthermore, these locations represent various degrees of limnological characteristics and anthropogenic influences, in particular electric power generation, public water supply and tourism (Julio et al., 2005).

\section{Sampling procedure}

Oligochaeta sampling was performed in July (dry season) and November (rainy season) of 2001 in the littoral and profundal zones, close to the dams, from 30 reservoirs using a modified Petersen grab $\left(0.0180 \mathrm{~m}^{2}\right)$. In each station, we obtained three samples for biological analysis and one for analysis of granulometry and organic matter content of the sediment.

The samples were pre-sorted in a graded sieve system (with mesh sizes 2, 1 and $0.2 \mathrm{~mm}$ ). The material collected in the smallest mesh was preserved in $4 \%$ formaldehyde, buffered with calcium carbonate (Bagatini et al., 2007) and later sorted using stereoscopic microscopy. All organisms found in different mesh sizes were preserved in buffered $4 \%$ formaldehyde.

Oligochaeta were identified to the most precise taxonomic level possible, using identification guides from Brinkhurst and Marchese (1992). After identification, organisms were rinsed in distilled water for one hour to remove excess formaldehyde. Specimens were then dried at $60{ }^{\circ} \mathrm{C}$ for $24 \mathrm{~h}$, cooled in desiccator and weighed on a microscale with $10^{-7} \mathrm{~g}$ precision (Sartorius Ultramicro). The biomass of each species was recorded in milligrams of dry weight per square metre $\left(\mathrm{mg}_{\mathrm{m}} \mathrm{m}^{-2}\right)$.

The measured environmental variables included water temperature, $\mathrm{pH}$ (pHmeter-Digimed), electric conductivity (condutivimeter Digimed) and dissolved oxygen (oxymeter-YSI). All variables were measured close to the bottom of the littoral and profundal zones of the reservoirs. To determine the granulometric composition of the sediment, we used the Wentworth scale (Wentworth, 1922). According to Suguio (1973), the size of sediment grain is classified as pebbles $(4.00 \mathrm{~mm})$, granules $(2.00 \mathrm{~mm})$, very coarse sand $(1.00 \mathrm{~mm})$, coarse sand $(0.50$ $\mathrm{mm})$, medium sand $(0.25 \mathrm{~mm})$, fine sand $(0.12 \mathrm{~mm})$, very fine sand $(0.63 \mathrm{~mm})$ and mud $(<0.63 \mathrm{~mm})$. The percentage of organic matter in sediment was estimated through sub-sample burning in a muffle furnace at $560{ }^{\circ} \mathrm{C}$ for $4 \mathrm{~h}$.

\section{Statistical analysis}

Principal component analyses (PCA) were performed to discriminate the distribution pattern of the sample units based on environmental variables (water temperature, dissolved oxygen, $\mathrm{pH}$, electrical conductivity, sediment type and organic matter) from littoral and profundal zones of the reservoirs. All these data (except $\mathrm{pH}$ ) were log transformed, and PCA axes were selected according to Broken-Stick criteria (Jackson, 1993).

The trophic status index (TSI) of Carlson (1977), modified by Toledo et al. (1983), was used to characterize the trophic status of the reservoirs. 


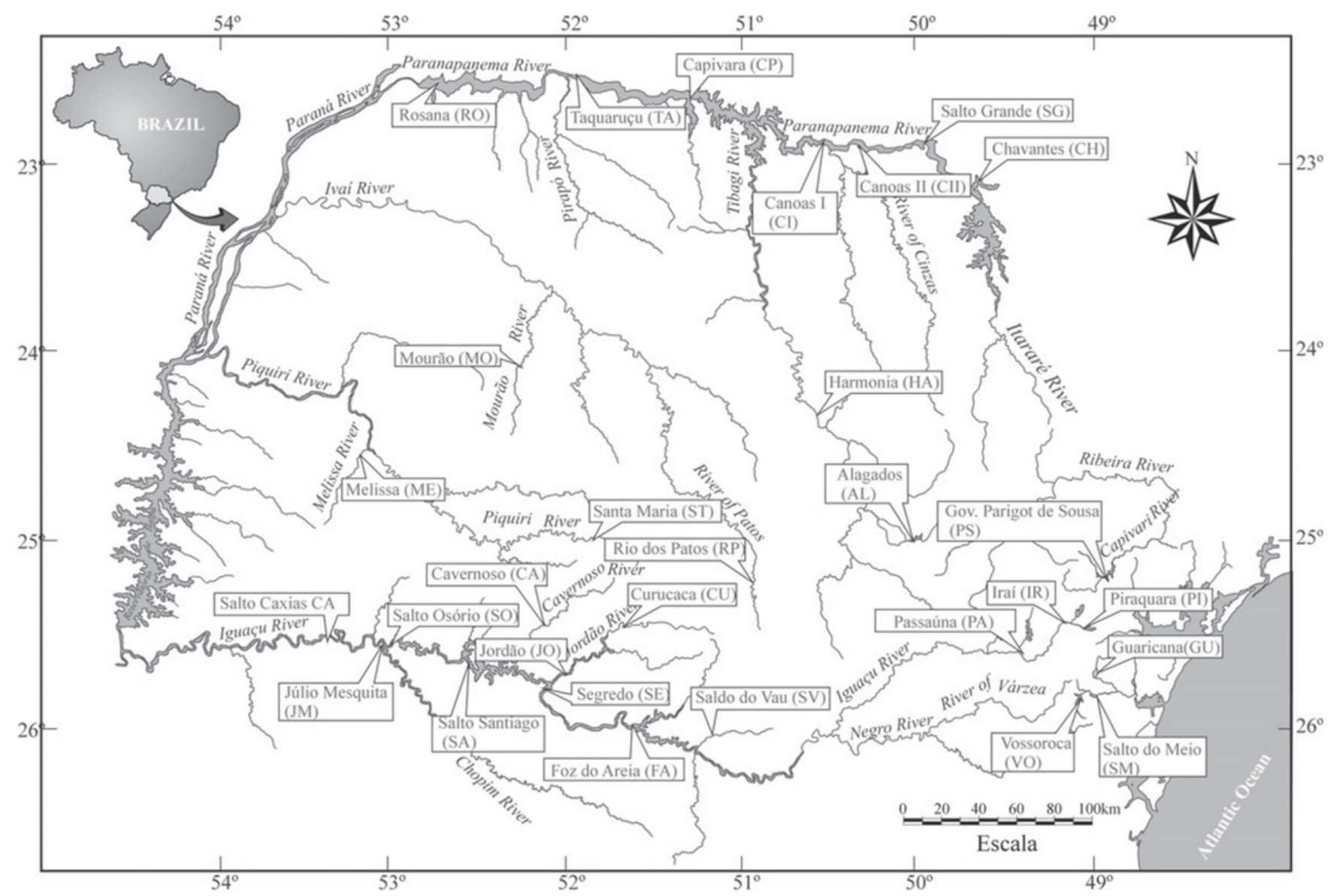

Fig. 1. Location of the 30 reservoirs of Paraná state.

The difference in Oligochaeta species composition was further tested with respect to differences between zones, including hydrological period, trophic status and watersheds, through a multiple response permutation procedure (MRPP). This is a non-parametric procedure based on Sørensen distance, which tests for differences in the assemblage structure among previously defined groups (Zimmerman et al., 1985).

A non-parametric ANOVA (Kruskal-Wallis) or Mann-Whitney was performed to test for possible differences in species richness and biomass of Oligochaeta, among zones, hydrological periods, trophic status and watersheds. Since the homoscedasticity assumption was not accepted for the analysed attributes, a parametric ANOVA could not be performed.

The environment-species relationship was tested using redundancy analyses (RDA) with a Hellinger transformation to the abiotic data matrix and the standardized environmental variables (root square). The global significance of the RDA axes was analysed by a permutation test (Legendre et al., 2011). To observe which environmental variables, granulometric or limnological, influenced variability among Oligochaeta community, we used a partitioning procedure of inertia (Borcard et al., 1992; Peres-Neto et al., 2006).

The Kruskal-Wallis non-parametric ANOVA and the Mann-Whitney test were performed using Statistical software version 7.1 (Stat Soft Inc., 2005) and PCA and MRPP were performed using PC-ORD software (McCune and Mefford, 1999). RDAs were developed with R software version 2.14.1 (R Core Team, 2011) using the VEGAN package (Oksanen et al., 2011).

\section{Results}

\section{Abiotic variables}

Mean water temperature ranged from 16.10 to $24.10^{\circ} \mathrm{C}$ in the littoral zone of reservoirs, while in the profundal zone, values ranged from 12.30 to $22.70{ }^{\circ} \mathrm{C}$. Higher depths were measured in profundal zones $(3.70-135.00 \mathrm{~m})$ than in littoral zones, which were shallower $(0.45-6.75 \mathrm{~m})$, except to Salto Santiago reservoir $(30.00 \mathrm{~m})$ and Salto Caxias $(27.00 \mathrm{~m})$. In these reservoirs, it was not possible to sample close to the shore because of the abundant presence of submerged trees. The mean $\mathrm{pH}$ values in the littoral (6.20$8.30)$ and the profundal (5.10-8.20) zones generally showed little variation, but significant variation was observed in electrical conductivity and dissolved oxygen concentration in the two zones. Electrical conductivity values ranged from 21.15 to $126.8 \mu \mathrm{S} . \mathrm{cm}^{-1}$ in the littoral zone and 21.55 to $141.80 \mu \mathrm{S} . \mathrm{cm}^{-1}$ in the profundal zone of the reservoirs. Lower values of dissolved oxygen were 


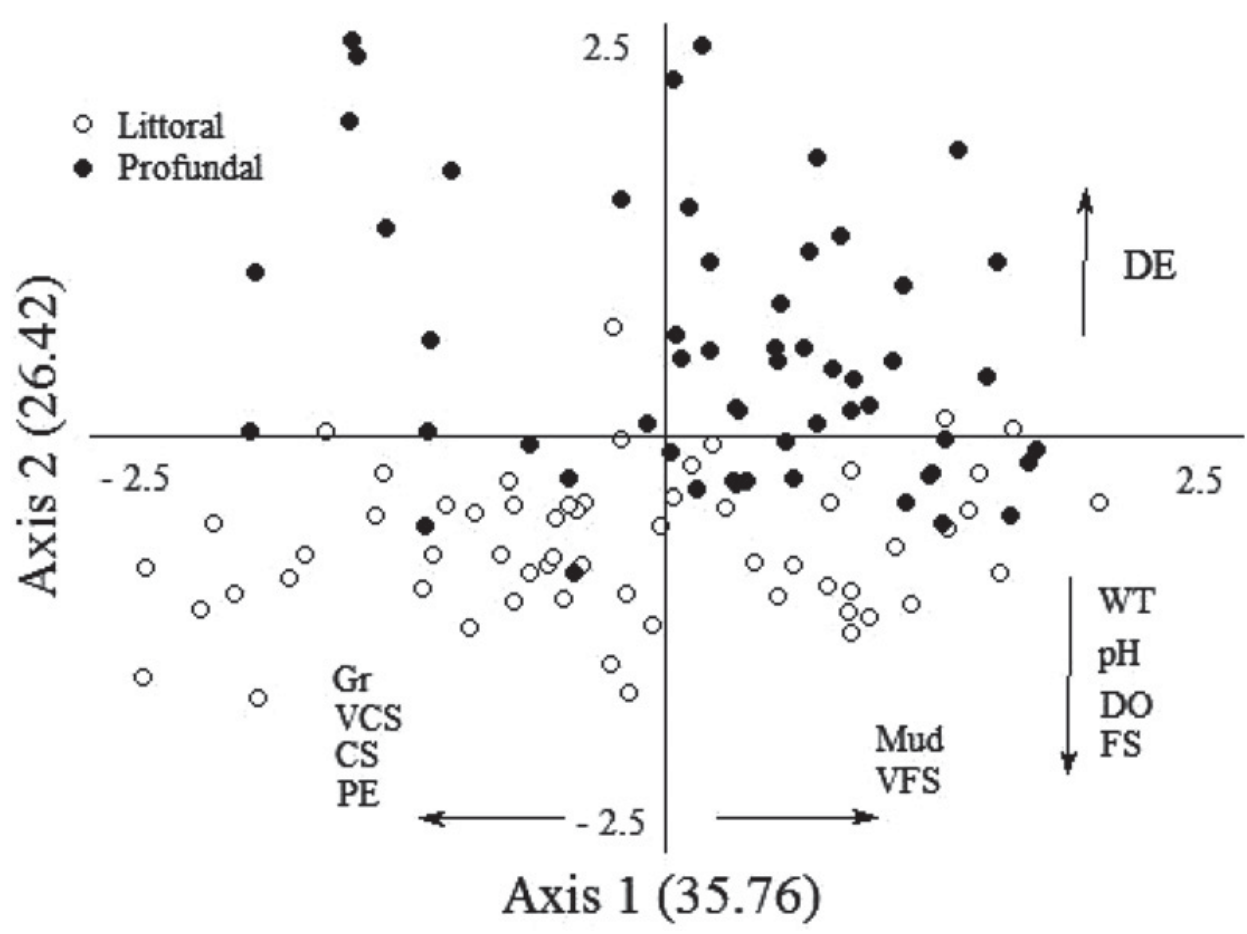

Fig. 2. Score distribution of PCA derived from physical and chemical variables of water and sediment. (WT, water temperature; DO, dissolved oxygen; DE, depth; Gr, granule; VCS, very coarse sand; CS, coarse sand; PE, pebbles; VFS, very fine sand.)

recorded in the profundal zone $\left(0.04-8.50 \mathrm{mg} . \mathrm{L}^{-1}\right)$, whereas higher values $\left(6.20-10.00 \mathrm{mg} . \mathrm{L}^{-1}\right)$ were recorded in the littoral zone. Organic matter content varied between $1.90 \%$ and $38.80 \%$ in the littoral zone and between $1.70 \%$ and $53.50 \%$ in the profundal zone. The sediment composition of the reservoirs was generally composed of a range of particles, ranging from 0.63 to $4.00 \mathrm{~mm}$ (see Appendices 1 and 2).

Regarding abiotic variables, PC1 showed that differences between reservoirs are due primarily to differences in sediment texture (Fig. 2). Reservoirs dominated by large sediment particles (granule, very coarse sand, coarse sand and pebbles) were negatively correlated with this axis, whereas reservoirs with sediment primarily composed of fine particles (mainly mud and very fine sand) were positively correlated. Differences between reservoir zones (littoral and profundal) in axis 2 were explored. The littoral zones characterized by shallower depths and higher values of water temperature, $\mathrm{pH}$, dissolved oxygen and higher percentages of fine sediment, were negatively correlated to axis 2, while depth was positively correlated (Fig. 2).

The trophic status of reservoirs varied according to the hydrological period (rainy and dry seasons), as indicated by the values of the TSI. Most of the reservoirs were classified as oligotrophic in both hydrological periods. Moreover, the reservoirs Melissa (ME), Rio dos Patos (RP), Passaúna (PA) and Salto do Meio (SM), which were considered oligotrophic during the dry season, were classified as mesotrophic in the rainy season, while the Julio Mesquita Filho (JM) reservoir changed from oligotrophic in the dry season to eutrophic in the rainy season.
Only the Iraí (IR) reservoir was classified as eutrophic in both periods (Table 1).

\section{Composition}

Sixteen species of Oligochaeta were found in the present survey, and these are distributed in six families (Enchytraeidae, Opistocystidae, Naididae, Tubificidae, Narapidae and Alluroididae). Twelve of these taxa belong to families Tubificidae and Naididae, with six taxa in each family. The absence of mature specimens of Bothrioneurum and some Aulodrilus precluded specific identification of these genera. The most common species were Opistocysta funiculus, Pristina breviseta, Dero (Dero) digitata, Stephensoniana trivandrana, Aulodrilus pigueti and Bothrioneurum sp. in the studied reservoirs (Table 2).

The Enchytraeidae (non-identified - NI) Pristina americana and Aulodrilus sp. occurred only in the littoral zones, while Tubificidae (NI) was found in the profundal zones only. The composition of the oligochaete communities was similar in both hydrological periods. Significant differences in composition were observed among reservoirs with different trophic states. All 16 taxa were recorded in the oligotrophic reservoirs and Enchytraeidae (NI), Pristinella longisoma, Aulodrilus sp., Branchiura sowerbyi, Narapa bonettoi and Brinkhurstia americanus were absent from mesotrophic and eutrophic reservoirs. P. americana, D. (D.) digitata, Dero (Aulophorus) borellii, Limnodrilus hoffmeisteri and Bothrioneurum sp. occurred in mesotrophic reservoirs and did not appear in the eutrophic reservoirs. Only four oligochaete species, O. funiculus, 
Table 1. Carlson Trophic Index modified by Toledo (1983) for 30 neotropical reservoirs. (TSI, trophic status index; TSC, trophic status category; D, dry period; R, rainy period; OL, oligotrophic reservoir; ME, mesotrophic reservoir; EU, eutrophic reservoir. The names and codes of the reservoirs are in Fig. 1.)

\begin{tabular}{|c|c|c|c|c|c|c|c|c|c|}
\hline \multirow[b]{2}{*}{ Reservoirs } & \multicolumn{2}{|c|}{ TSI } & \multicolumn{2}{|c|}{ TSC } & \multirow[b]{2}{*}{ Reservoirs } & \multicolumn{2}{|c|}{ TSI } & \multicolumn{2}{|c|}{ TSC } \\
\hline & $\mathrm{D}$ & $\mathrm{R}$ & $\mathrm{D}$ & $\mathrm{R}$ & & $\mathrm{D}$ & $\mathrm{R}$ & $\overline{\mathrm{D}}$ & $\mathrm{R}$ \\
\hline$\overline{\mathrm{ST}}$ & 27.4 & 41.5 & $\mathrm{OL}$ & $\mathrm{OL}$ & SE & 43.6 & 35.8 & OL & $\mathrm{OL}$ \\
\hline ME & 43.0 & 50.2 & $\mathrm{OL}$ & $\mathrm{ME}$ & FA & 39.0 & 39.5 & OL & OL \\
\hline MO & 38.4 & 38.9 & $\mathrm{OL}$ & OL & OS & 35.5 & 37.6 & OL & $\mathrm{OL}$ \\
\hline RP & 40.8 & 44.9 & $\mathrm{OL}$ & ME & $\mathrm{CU}$ & 31.8 & 29.2 & OL & OL \\
\hline HA & 42.9 & 41.8 & $\mathrm{OL}$ & $\mathrm{OL}$ & $\mathrm{CH}$ & 27.7 & 36.7 & $\mathrm{OL}$ & OL \\
\hline $\mathrm{AL}$ & 42.2 & 41.9 & OL & $\mathrm{OL}$ & SG & 35.7 & 31.7 & $\mathrm{OL}$ & $\mathrm{OL}$ \\
\hline $\mathrm{JM}$ & 41.1 & 54.8 & $\mathrm{OL}$ & EU & $\mathrm{CP}$ & 38.0 & 34.3 & $\mathrm{OL}$ & OL \\
\hline SA & 31.6 & 39.5 & $\mathrm{OL}$ & $\mathrm{OL}$ & CII & 40.7 & 40.1 & $\mathrm{OL}$ & $\mathrm{OL}$ \\
\hline $\mathrm{CA}$ & 34.7 & 42.2 & $\mathrm{OL}$ & $\mathrm{OL}$ & CI & 38.9 & 36.1 & $\mathrm{OL}$ & OL \\
\hline PI & 30.5 & 33.4 & $\mathrm{OL}$ & $\mathrm{OL}$ & TA & 39.7 & 36.5 & $\mathrm{OL}$ & OL \\
\hline IR & 57.4 & 63.6 & EU & EU & $\mathrm{RO}$ & 41.8 & 33.5 & $\mathrm{OL}$ & OL \\
\hline PA & 30.5 & 46.8 & OL & $\mathrm{ME}$ & PS & 35.0 & 35.3 & $\mathrm{OL}$ & $\mathrm{OL}$ \\
\hline JO & 29.5 & 27.4 & $\mathrm{OL}$ & $\mathrm{OL}$ & VO & 31.8 & 34.3 & $\mathrm{OL}$ & OL \\
\hline SV & 25.8 & 28.2 & $\mathrm{OL}$ & $\mathrm{OL}$ & SM & 40.0 & 45.5 & OL & ME \\
\hline $\mathrm{CV}$ & 29.4 & 37.6 & OL & $\mathrm{OL}$ & GU & 43.3 & 36.9 & $\mathrm{OL}$ & $\mathrm{OL}$ \\
\hline
\end{tabular}

Table 2. Species composition and mean biomass of Oligochaeta in neotropical reservoirs in different zones, trophic status and watersheds. (L, littoral zone; P, profundal zone; D, dry period; R, rainy period; O, oligotrophic reservoir; M, mesotrophic reservoir; E, eutrophic reservoir; Pi, Piquiri watershed; Iv, Ivaí watershed; Ti, Tibagi watershed; Ig, Iguaçu watershed; Pa, Paranapanema watershed; Li, Litorânea watershed.)

\begin{tabular}{|c|c|c|c|c|c|c|c|c|c|c|c|c|c|}
\hline & \multicolumn{2}{|c|}{ Zones } & \multicolumn{2}{|c|}{ Periods } & \multicolumn{3}{|c|}{ Trophic state } & \multicolumn{6}{|c|}{ Watersheds } \\
\hline & $\overline{\mathrm{L}}$ & $\mathrm{P}$ & $\mathrm{D}$ & $\mathrm{R}$ & $\mathrm{O}$ & $\mathrm{M}$ & $\mathrm{E}$ & $\overline{\mathrm{PI}}$ & IV & TI & $\mathrm{IG}$ & $\mathrm{PA}$ & $\mathrm{LI}$ \\
\hline \multicolumn{14}{|l|}{ Enchytraeidae } \\
\hline Enchytraeidae (NI) & . & & • & & - & & & & & & • & . & \\
\hline \multicolumn{14}{|l|}{ Opistocystidae } \\
\hline Opistocysta funiculus Cordero, 1948 & - & • & • & - & • & & • & - & - & • & - & - & - \\
\hline \multicolumn{14}{|l|}{ Naididae } \\
\hline Pristina breviseta Bourne, 1891 & - & - & • & • & • & & - & • & - & - & - & • & • \\
\hline Pristina americana Cernosvitov, 1937 & - & & - & • & - & - & & & & & & & - \\
\hline Dero (Dero) digitata (Müller, 1773) & ○ & . & - & . & - & • & & & . & • & $\bullet$ & & . \\
\hline Dero (Aulophorus) borellii Michaelsen, 1900 & $\cdot$ & - & - & - & • & • & & & & & & • & \\
\hline Stephensoniana trivandrana (Aiyer, 1926) & . & . & . & . & . & & • & . & . & & . & . & . \\
\hline Pristinella longisoma Harman, 1977 & - & - & • & - & • & & & & & & - & - & - \\
\hline \multicolumn{14}{|l|}{ Tubificidae } \\
\hline Limnodrilus hoffmeisteri Claparede, 1862 & - & - & • & • & • & • & & & & & • & & - \\
\hline Aulodrilus pigueti Kowalewski, 1914 & - & - & • & - & - & & • & • & • & & - & - & - \\
\hline Aulodrilus sp. & • & & . & . & • & & & & & & - & & . \\
\hline Bothrioneurum sp. & - & 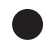 & $\bullet$ & 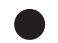 & 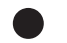 & - & & - & 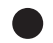 & • & - & $\bullet$ & 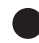 \\
\hline Branchiura sowerbyi Beddard, 1892 & - & 0 & • & . & . & & & & & & • & 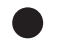 & . \\
\hline \multicolumn{14}{|l|}{ Narapidae } \\
\hline Narapa bonettoi Righi \& Varela, 1983 & • & - & - & • & • & & & & & & • & • & \\
\hline Tubificidae (NI) & & - & . & . & . & . & & & & . & & . & . \\
\hline \multicolumn{14}{|l|}{ Alluroididae } \\
\hline Brinkhurstia americanus Brinkhurst, 1964 & . & . & - & - & • & & & & . & & . & & - \\
\hline
\end{tabular}

Biomass: • < 1000 mg.m ${ }^{-2}$, • 1000-5000 mg.m ${ }^{-2}, \bigcirc>5000$ mg.m ${ }^{-2}$.

$P$. breviseta, S. trivandrana and $A$. pigueti, were found in the eutrophic reservoirs, these taxa did not occur in the mesotrophic reservoirs. Opistocysta funiculus, $P$. breviseta and Bothrioneurum sp. were recorded in all six watersheds; on the other hand some species, e.g., $P$. americana and $D$. (A.) borellii were exclusive to the Litorânea and Paranapanema watersheds, respectively. Enchytraeidae (NI) and N. bonettoi were observed in the Iguaçu and Paranapanema watersheds, and the tubificids
L. hoffmeisteri and Aulodrilus sp. in Iguaçu and Litorânea (Table 2).

According to the MRPP, the Oligochaeta composition differed significantly between littoral and profundal zones ( $A=0.004 ; T=-1.943 ; P=0.049)$, among trophic status ( $A=0.011 ; T=-3.344 ; P=0.006)$ and among watersheds $(A=0.070 ; T=-13.440 ; P=0.000)$. However, this difference was not significant for the two hydrological periods ( $A=0.003 ; T=-0.163 ; P=0.351)$. 

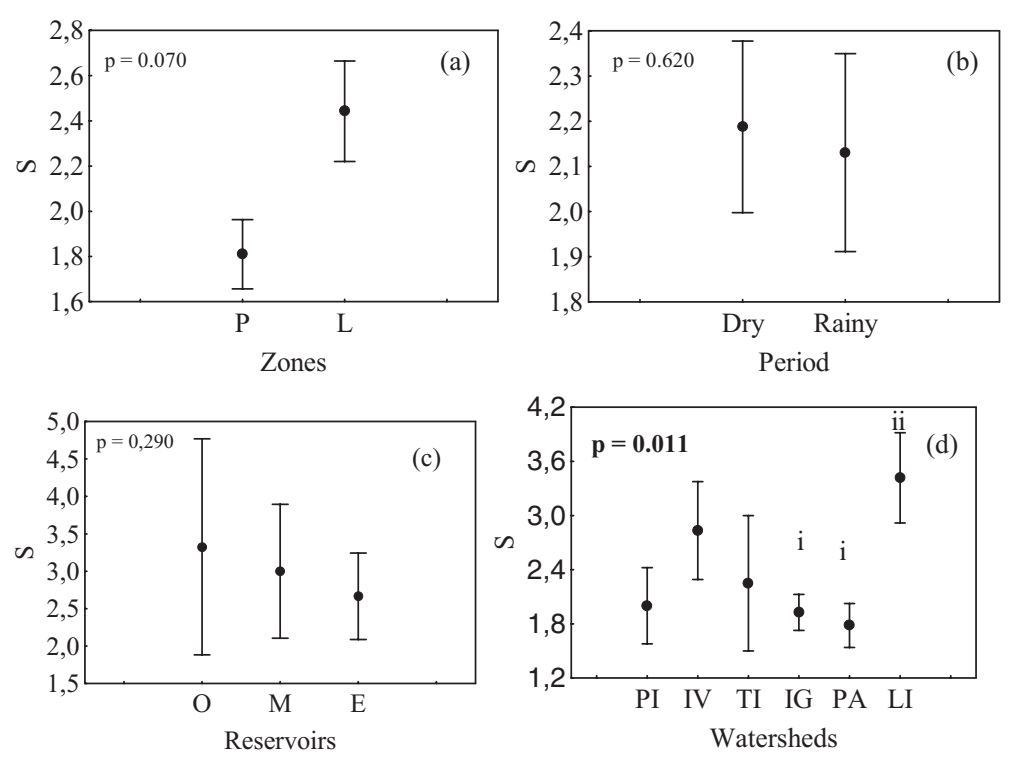

Fig. 3. Mean values and standard error of species richness (S) in different zones (a), hydrological periods (b), trophic status (c) and watersheds (d). (P, profundal zone; L, littoral zone; PI, Piquiri watershed; IV, Ivaí watershed; TI, Tibagi watershed; IG, Iguaçu watershed; PA, Paranapanema watershed; LI, Litorânea watershed.)

\section{Species richness}

The mean species richness of Oligochaeta was higher in the littoral zone (Mann-Whitney, $P=0.070$ ) and in the dry seasons (Figs. 3a and b). Considering the trophic status, the richness values were similar among the reservoirs with higher values in the oligotrophic reservoirs (Fig. 3c), but the difference was not significant (KruskalWallis $P>0.05)$. The richness was higher in Litorânea and Ivaí watersheds (Fig. 3d), and this difference was significant between the Litorânea watershed and the Iguaçu and Paranapanema watersheds (Kruskal-Wallis, $P=0.006)$.

\section{Biomass}

Specific biomass was higher $\left(>5000 \mathrm{mg} \cdot \mathrm{m}^{-2}\right)$ in Bothrioneurum sp. and B. sowerbyi. These average values were observed in the profundal zone $\left(8988.628 \mathrm{mg} . \mathrm{m}^{-2}\right)$, during the rainy season, in oligotrophic reservoirs and in the Ivaí and Litorânea watersheds for Bothrioneurum sp., and only in the Paranapanema watershed for B. sowerbyi. Dero (Dero) digitata was also quite abundant (with biomass between 1000 and $5000 \mathrm{mg} \cdot \mathrm{m}^{-2}$ ) mainly in the littoral zone (2098.367 mg.m ${ }^{-2}$ ) and during the rainy season. Considering the trophic status of the reservoirs and the watersheds, higher biomass was observed in oligotrophic ones and Iguaçu watershed. The biomass of other species was below $1000 \mathrm{mg} \cdot \mathrm{m}^{-2}$ (Table 2).

The higher mean oligochaete biomass, mainly of Bothrioneurum sp. and Branchiura sowerbyi (Table 2), was observed in the profundal zone $\left(321.830 \mathrm{mg} . \mathrm{m}^{-2}\right.$ ) (Fig. 4a). Higher mean values of biomass were recorded in the dry season $\left(184.630 \mathrm{mg} . \mathrm{m}^{-2}\right.$ ) (Fig. 4b) with higher biomasses mostly occurring in $D .(D$.$) digitata and$ Bothrioneurum sp. (Table 2). Considering the trophic status and watersheds, the biomass was higher in mesotrophic reservoirs (2048.280 mg.m ${ }^{-2}$ ) and in the Litorânea $\left(671.840 \mathrm{mg} \cdot \mathrm{m}^{-2}\right)$ and Ivaí $\left(456.870 \mathrm{mg} \cdot \mathrm{m}^{-2}\right)$ watersheds (Figs. 4c and d). Highest biomass was represented by Bothrioneurum sp. in the mesotrophic reservoirs and in both watersheds (Table 2).

Biomass differed between zones (Mann-Whitney; $U=13116 ; \quad P=0.001), \quad$ hydrological $\quad$ periods (Mann-Whitney; $U=14030 ; P=0.027$ ), trophic status (Kruskal-Wallis; $H=6.630 ; P=0.0363$ ) and watersheds (Kruskal-Wallis; $H=21.880 ; \quad P=0.0006$ ), where the Litorânea watershed differed significantly from the Tibagi and Iguaçu watersheds (Fig. 4d).

\section{Species-environment relationship}

Water temperature, $\mathrm{pH}$, conductivity and trophic state index were the most important to describe the oligochaete communities gradients (Fig. 5a). As regards sediment type, granules, very coarse sand, medium sand, mud and sediment organic matter were most important to characterize the community composition of oligochaetes (Fig. 5b).

Some environmental variables showed recurrent associations with individual species. The trophic state index was positively correlated with $O$. funiculus in littoral areas, but correlated negatively with $N$. bonettoi. Electrical conductivity was an important variable during the rainy season and was positively correlated with B. sowerbyi. Water temperature was positively correlated with $N$. bonettoi and negatively with Bothrioneurum. Bothrioneurum was negatively correlated with $\mathrm{pH}$ in all RDAs performed. 

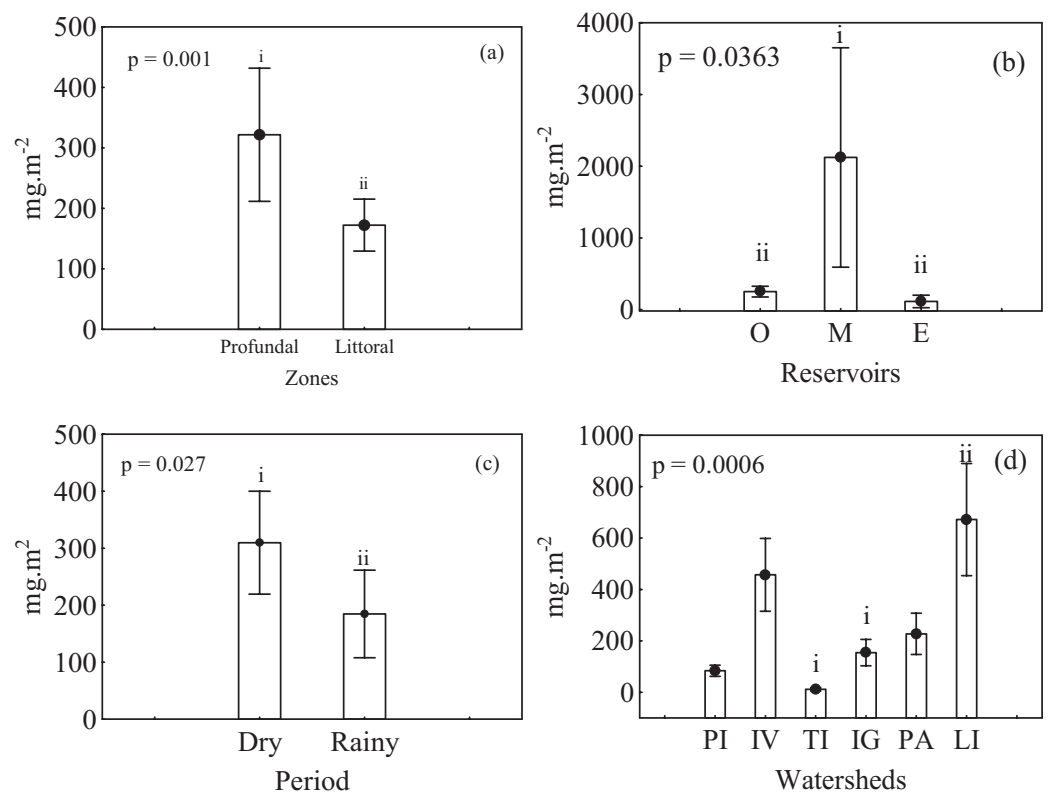

Fig. 4. Mean values and standard error of Oligochaeta biomass (mg.m ${ }^{-2}$ ) according to zones (a), trophic status (b), hydrological period (c) and watersheds (d). (Different codes (i and ii) indicate significant differences.)

Sediment type correlated positively with the species $N$. bonettoi, D. digitata and $P$. breviseta, while it was negatively correlated with $B$. sowerbyi, $O$. funiculus, P. longisoma and Bothrioneurum.

The abiotic and sedimentological variables explained 57 and $80 \%$, respectively, of Oligochaeta community variation. In inertia partitioning, the sedimentological fraction was more important to the community structure, mainly during the dry period, where the sediment explained 41 and $38 \%$ of data variability (littoral and profundal zone, respectively) and the abiotic data explained 18 and $20 \%$ (littoral and profundal zone, respectively) (Fig. 6).

\section{Discussion}

Our results showed that, in the 30 reservoirs studied, sediment type was the main driver of the Oligochaeta community composition, richness and biomass. Several other local factors, including variation in depth and in dissolved oxygen content also influenced the Oligochaeta community structure. Less pronounced was the effect of regional factors related to hydrological period and watersheds, as observed in the PCA.

The influence of local and regional factors driving species diversity has been recently discussed in different biological communities (Bini et al., 2003; Stendera and Johnson, 2005; Johnson et al., 2007). Studies describing assemblages of benthic macroinvertebrates have observed that local processes may be more important for the structure of these communities than regional processes (Stendera and Johnson, 2005; Johnson et al., 2007), and the factors may indeed be independent (Johnson and Goedkoop, 2002). With respect to Oligochaeta, variations in species composition related to different regional and local scales have been referred in several studies (Särkkä, 1992; Real and Prat, 1992, Alves et al., 2008). Changes in the characteristics of limnology and sediment observed at both local (zones and trophic status) and regional scales (watersheds and periods) significantly influence species richness and biomass of Oligochaeta in our study.

The environmental conditions of the littoral zone are favourable to a large number of invertebrate taxa (Moretto et al., 2003) including Oligochaeta (Dornfeld et al., 2006). The presence of larger sediment particles (pebbles and granules) and water temperature, in some reservoirs, contributed to increases in species richness as well as to the presence of the naidids $D$. (D.) digitata and $P$. breviseta. According to Erséus et al. (2005), Dero is a genus characteristic of warmer conditions, as observed in neotropical regions.

The total biomass of Oligochaeta and the tubificid Bothrioneurum sp. increased in the littoral zone, in both shallow and deep littoral zones (see Appendices 1 and 2), with higher concentrations of dissolved oxygen. Some studies have stated that the depth exerts a significant effect on invertebrate biomass (Martinez-Anselmi and Prat, 1984, Särkkä, 1992, Verneaux and Aleya, 1998). According to Särkkä (1992), the environmental requirements of different Oligochaeta species could be related to several depths in the environments. Similar results were described by Verneaux and Aleya (1998) on Chironomidae fauna from environments with a distinct trophic status. These authors showed the efficiency and importance of bathymetric studies in characterizing environmental preferences of organisms, and describing community variation with depth.

Tubificidae and Naididae were among the most abundant groups in Oligochaeta communities of several 

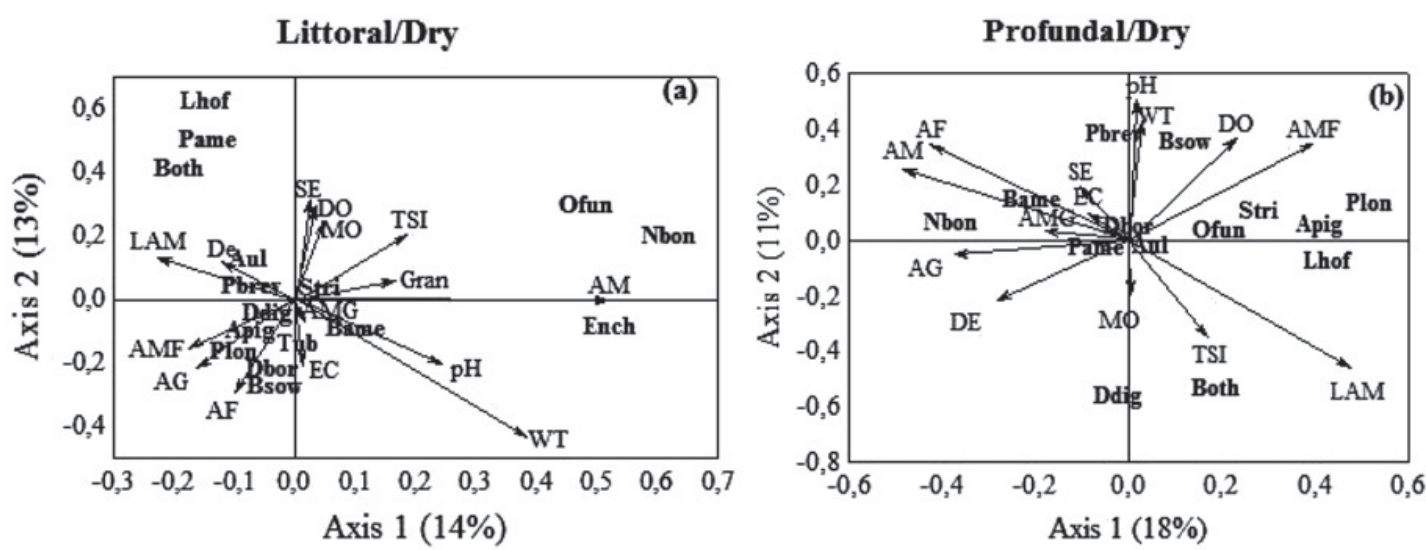

Littoral/Rainy
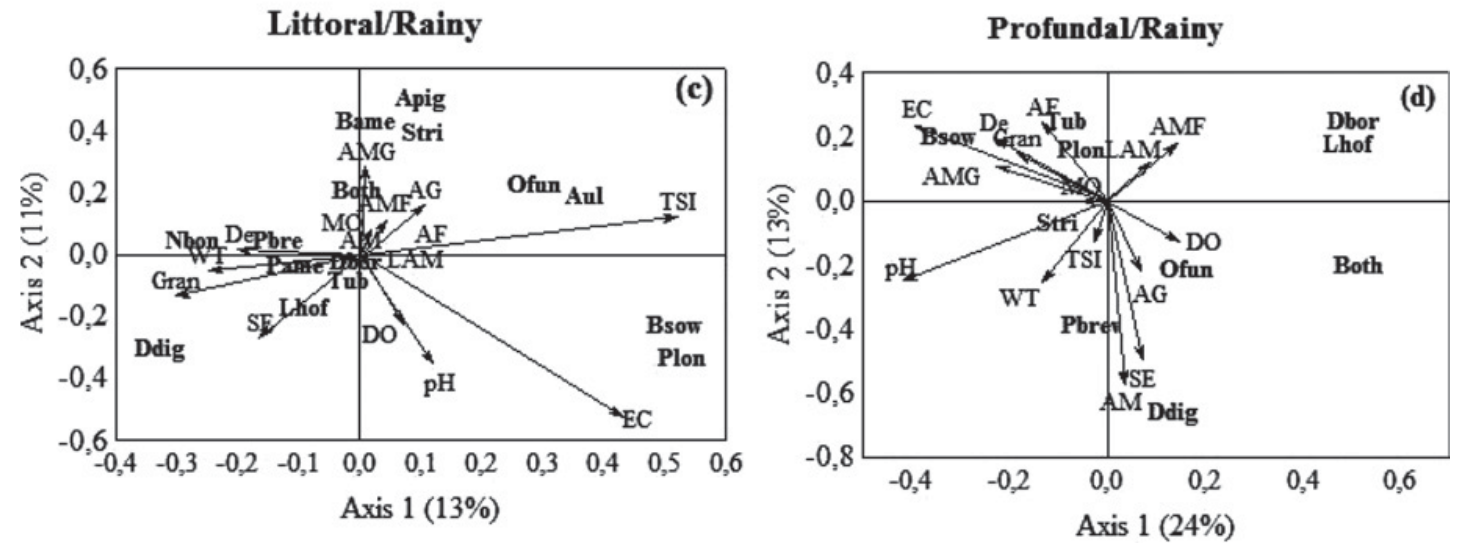

Fig. 5. Biplot species-environment of each redundancy analysis in reservoirs of Paraná state, Brazil. (a) Littoral zone/rainy period, (b) littoral zone/dry period, (c) profundal zone/rainy period and (d) profundal zone/dry period.

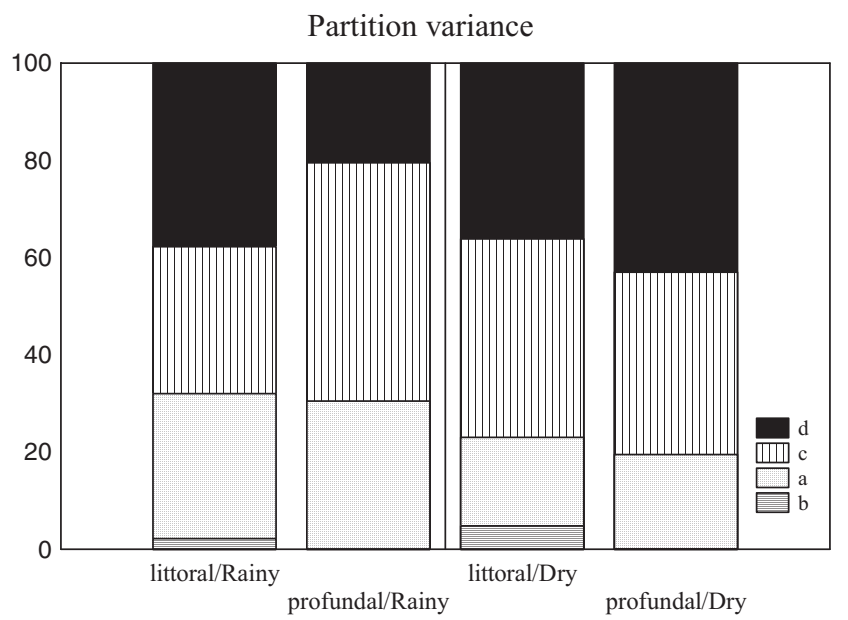

Fig. 6. Inertia partitioning showing the importance of limnological and sediment predictors to the community structure of Oligochaeta in reservoirs of Paraná state, Brazil. (Variation explained by: a, limnology; b, granulometric texture; c, interaction between limnology and granulometric texture; d, environmental data.)

aquatic ecosystems, consistent with several previous studies (Chauvet et al., 1993; Alves and Lucca, 2000; Peralta et al., 2002; Dornfeld et al., 2006; Martins et al., 2011). Tubificidae may have higher biomass compared with Naididae, simply because they are larger. Bothrioneurum sp. has a cosmopolitan distribution (Schenková et al., 2006) and has been able to colonize a wide variety of environments, whereas the presence of naidids depends on periphyton availability (Sporka, 1996). In littoral zones, where light penetration is high, periphyton communities are more common (Rodrigues et al., 2005b). Hence, these regions are favourable for naidid development (Verdonschot, 1989) and are thus able to support a higher diversity of naidid taxa. Furthermore, reservoirs with decreased concentrations of organic matter and larger sediment particles were associated with Dero and particularly with Pristina (Schenková et al., 2001).

In general, the profundal zone was characterized by higher concentrations of organic matter, except in reservoirs with fine sediment. The higher mean Oligochaeta biomass in the profundal zone was primarily related to the presence of mud (direct and significant correlation between these variables). Tubificidae were the most abundant taxa and included Bothrioneurum sp., B. sowerbyi and L. hoffmeisteri. This family is known to live in organically enriched environments with fine sediment particles (Schenková et al., 2001; Dornfeld et al., 2006). The preference for this type of habitat may be due to the fact that most tubificids feed on bacteria and organic matter (Verdonschot, 1989; Rîsnoveanu and Vãdineanu, 2003), both of which are available more in the profundal zones 
(Peralta et al., 2002; Van Duinen et al., 2006). A study performed in Lake Baikal showed that food availability was a limiting factor for Oligochaeta distribution in deep regions of the lake (Martin et al., 1999). Furthermore, Schenková et al. (2006) demonstrated that Bothrioneurum vejdovskyanum showed a preference for habitats with little water level fluctuation and low substrate turnover. These features are typical of lentic environments, including some reservoirs.

Oligochaeta species can be abundant in deep zones of aquatic environments (Real and Prat, 1992; Martin, 1996; Bonomi and Pasteris, 2006; Dornfeld et al., 2006) since they present adaptations allowing them to survive in less favourable conditions. Gills and respiratory appendages allow some species to survive in environments where oxygen is limited (Martin, 1996; Raposeiro et al., 2009). An example is the tubificid $B$. sowerbyi and the naidid $D$. (A.) borelli, both of which present respiratory appendages and are abundant in deeper reservoirs where the oxygen levels were generally low. A study carried out by Martinez-Anselmi and Prat (1984), in 63 Spanish reservoirs, showed that the depth was not a critical factor for Oligochaeta species and that Naididae in particular are able to survive at considerable depths in reservoirs, since oxygen levels close to the bottom were sufficient for these species.

The trophic status of reservoirs, as well as its geographic distribution over the watersheds, contributed to differences in the Oligochaeta community structure. In general, species diversity and biomass were higher in mesotrophic reservoirs. The higher nutrient concentrations of these environments contributed to an increase in primary productivity of phytoplankton and periphyton (Rodrigues et al., 2005a, 2005b) as well as of bacteria (Pagioro et al., 2005), which subsequently increases food resource to the macroinvertebrates. Colonizing experiments emphasized that Oligochaeta are important to the detritivorous food chain, because they have distinct abilities to exploit different food sources (Martins et al., 2011).

The increase in the productivity associated with higher nutrient input generally stimulates increasing species abundance, until the dissolved oxygen supply has been entirely consumed. In the profundal zone of a eutrophic reservoir (Iraí reservoir), we recorded low concentrations of dissolved oxygen, while, in the mesotrophic reservoirs, the oxygen supply was higher. This fact could explain the increased biomass associated with mesotrophic reservoirs as compared with eutrophic reservoirs. Mesotrophic reservoirs contained adequate levels of dissolved oxygen, which may support increased biomass, and species richness.

The location of mesotrophic reservoirs in the Litorânea watershed accounts for elevated species diversity of the Oligochaeta community. The Litorânea watershed is isolated in the Sea Mountain Range and, consequently, has less anthropogenic influence compared with the other watersheds. This fact may contribute to higher biomass and diversity of the associated community.
Different methods have been used to describe invertebrate communities in the context of environmental trophic status (Saether, 1979; Real and Prat, 1992; Verneaux and Aleya, 1998; Takahashi et al., 2008). Oligochaeta has been used successfully in trophic classifications (Slepukhina, 1984; Verdonschot, 1989; Rossaro et al., 2006). Nevertheless, a study carried out by Lafont (1984) reported some difficulties in the use of Oligochaeta as a tool to evaluate the impact of human activities on aquatic ecosystems, since each habitat category contributes to the dynamics of this group. Moreover, several authors have shown that the organisms will not always be reliable indicators of environmental conditions (Saether, 1979; Lafont, 1984; Verdonschot, 1989; Verneaux and Aleya, 1998).

In conclusion, the composition, richness and biomass of Oligochaeta communities in neotropical reservoirs were directly influenced by local environmental variation. We were able to corroborate our initial hypothesis that sediment grain size is the most important factor determining the Oligochaete community structure. Depth also contributes to the local community structure. The results obtained in the present study also showed a significant influence of trophic status on diversity and biomass of the Oligochaeta class, confirming our (second) hypothesis that low species richness is sustained in most trophic reservoirs. Mesotrophic environments, however, were more favourable to communities in terms of biomass, contrary to our initial hypothesis.

Acknowledgements. CNPq/PRONEX and FINEP/CT-HIDRO provided financial support for this study. We express our gratitude to all colleagues who helped us in the field. Copel helped with sampling, Nupélia provided considerable logistic support. Cassiana de Lima Amaro sorted the samples; Maria Célia Montanholi-Martins provided assistance for the identification of Oligochaeta taxa. Dr Fábio Amôdeo Lansac-Tôha and Dr Luiz Felipe Machado Velho made valuable suggestions during the preparation of this manuscript. We acknowledge the helpful comments of Dr Koen Martens on a former version, and we thank Jaime Pereira for drawing the map. The first author is also grateful to $\mathrm{CNPq}$ for a PhD scholarship. American Journal experts proofread for the English text.

\section{References}

Aiyer K.S.P., 1926. Notes on the aquatic Oligochaeta of Travancore, II. Ann. Magas. Nat. Hist. 18, 131-142.

Alves R.G. and Lucca J.V., 2000. Oligochaeta (Annelida: Clitellata) como indicador de poluição orgânica em dois córregos pertencentes à Bacia do Ribeirão do Ouro Araraquara (São Paulo, Brasil). Braz. J. Ecol., 2, 112-117.

Alves R.G., Marchese M.R. and Escarpinati S.C., 2006. Oligochaeta (Annelida, Clitellata) in lotic environments in the state of São Paulo, Brazil. Iheringia Zool., 96, 431-435.

Alves R.G., Marchese M.R. and Martins R.T., 2008. Oligochaeta (Annelida, Clitellata) of lotic environments at Parque Estadual Intervales (São Paulo, Brazil). Biota Neotrop., 
8, 69-72. Available online at: http://www.biotaneotropica. org.br/v8n1/en/abstract?article + bn01708012008.

Bagatini Y.M., Higuti J. and Benedito E., 2007. Temporal and longitudinal variation of Corbicula fluminea (Mollusca, Bivalvia) biomass in the RosanaReservoir, Brazil. Acta Limnol. Bras., 19, 117-130.

Beddard F.E., 1892. A new branchiate Oligochate (Branchiura sowerbyi). Quat. J. Microsc. Sci. 33, 325-341.

Benke A.C., Huryn A.D., Smock L.A. and Wallace J.B., 1999. Length mass relationships for freshwater macroinvertebrates in North America with particular reference to the southeastern United States. J. N. Am. Benthol. Soc., 18, 308-343.

Bini L.M., Velho L.F.M. and Lansac-Tôha F.A., 2003. The effect of connectivity on the relationship between local and regional species richness of testate amoebae (Protozoa, Rhizopoda) in floodplain lagoons of the Upper Paraná River, Brazil. Acta Oecol., 24, 145-151.

Bletter M., Amsler M., Ezcurra De Drago I. and Marchese M., 2008. Effects of stream hydraulics and other environmental variables on density of Narapa bonettoi (Oligochaeta) in the Paraná River system. River Res. Appl., 24, 1124-1140.

Bonomi G. and Pasteris A., 2006. From demographic strategies to mathematical models: trends in population dynamics studies of aquatic Oligochaeta. Hydrobiología, 564, 61-71.

Borcard D., Legendre P. and Drapeu P., 1992. Partialling out the spatial component of ecological variation. Ecology, 73, 1045-1055.

Bourne A.G., 1891. Notes on the naidiform Oligochaeta. Quat. J. Microsc. Sci., 32, 335-356.

Brinkhurst R.O., 1964. Studies on the North American aquatic Oligochaeta. I. Naididae and Opistocystidae. Proceed. Acad. Nat. Sci. Philadelp., 116, 195-230.

Brinkhurst R.O. and Marchese M.R., 1992. Guia para la identificacion de oligoquetos aquáticos continentales de Sud y Centro America, Associacion de Ciencias Naturales del Litoral, Santo Tomé, 207 p.

Carlson, R.E., 1977. A Trophic State Index for Lakes. Limnol. Ocean., 22, 361-369.

Cernosvitov L., 1937. Notes sur les Oligochaeta (Naididées et Enchytraeidées) de l' Argentine. Anales del Mus. Argent. Cienc. Nat. "Bernardino Rivadavia", 39, 136-157.

Chapman P.M., 2001. Utility and relevance of aquatic oligochaetes in ecological risk assessment. Hydrobiologia, 463, 149-169.

Chauvet E., Giani N. and Gessner M.O., 1993. Breakdown and invertebrate colonization of leaf litter in two contrasting streams: significance of Oligochaetes in a large river. Can. J. Fish. Aquat. Sci., 50, 488-495.

Claparède E., 1862. Le developpement d'Hydroïdes marins appartenant au genre Tubulaire. Verh. Schweiz. Naturf. Ges., 194-195.

Cordero E.H., 1948. Zur Kenntnis der Gattung Opisthocysta (Archioligochaeta). Commun. Zool. Mus. Hist. Nat. Montevideo, 50, 1-8.

Dornfeld C.B., Alves R.G., Leite M.A. and Espíndola E.L.G., 2006. Oligochaeta in eutrophic reservoir: the case of Salto Grande reservoir and their main affluent (America, São Paulo, Brazil). Acta Limnol. Bras., 18, 189-197.

Dufrêne M. and Legrendre P., 1997. Species assemblages and indicator species: the need for a flexible asymmetrical approach. Ecol. Monogr., 67, 345-366.
Erséus C., Rota E., Timm T., Grimm R., Healy B. and Lundberg S., 2005. Riverine and riparian clitellates of three drainages in southern Sweden. Ann. Limnol. - Int. J. Lim., 41, 183-194.

Friberg N., 2010. Pressure-response relationships in stream ecology: introduction and synthesis. Freshw. Biol., 55, 1367-1381.

Golterman H.L., Clymo R.S. and Ohmstad M.A.M., 1978. Methods for Physical and Chemical Analysis of Freshwaters. Blackwell Scientific Publication, London, 213 p.

Harman W.J., 1977. Three new species of Oligochaeta (Naididae) from the southeastem U.S. Proceed. Biol. Soc. Washing., 90, 483-490.

Harper D., 1992. Eutrophication of Freshwaters: Principles, Problems, and Restoration. Chapman \& Hall, New York, $327 \mathrm{p}$.

Jackson D.A., 1993. Stopping rules in principal components analysis: a comparison of heuristical and statistical approaches. Ecology, 74, 2204-2214.

Johnson R.K. and Goedkoop W., 2002. Littoral macroinvertebrate communities: spatial scale and ecological relationships. Freshw. Biol., 47, 1840-1854.

Johnson R.K., Furse M.T., Hering D. and Sandin L., 2007. Ecological relationships between stream communities and spatial scale: implications for designing catchment-level monitoring programmes. Freshw. Biol., 52, 939-958.

Julio, H.F., Thomaz S.M., Agostinho A.A. and Latini J.D., 2005. Distribuição e caracterização dos reservatórios. In: Rodrigues L., Thomaz S.M., Agostinho A.A. and Gomes L.C. (eds.), Biocenose em reservatórios: padrões espaciais e temporais, Rima, São Carlos, 1-17.

Kowalevski M., 1914. Rodzaj Aulodrilus Bretscher 1899 i jego przedstawicicle. Bull. Int. Acad. Sci. Lett. Cracovie, 54, 598-604.

Lafont M., 1984. Oligochaete communities as biological descriptors of pollution in the fine sediments of rivers. In: Bonomi G. and Erséus C. (eds.), Aquatic Oligochaeta. Hydrobiologia, $115,127-129$.

Lafont M., 1987. Production of Tubificidae in the littoral zone of Lake Léman near Thonon-les-Bains: a methodological approach. In: Brinkhurst R.O. and Diaz R.J. (eds.), Aquatic Oligochaeta. Hydrobiologia, 155, 179-187.

Legendre P., Oksanen J. and Ter Braak C.J.F., 2011. Testing the significance of canonical axes in redundancy analysis. Methods Ecol. Evol., 2, 269-277.

Lind O.T., Terrell T.T., Kimmel B.L., 1993. Problems in reservoir trophic-state classification and implications for reservoir management. In: Straškraba M., Tundisi J.G. (eds.), Comparative Reservoir Limnology and Water Quality Management, Kluwer Academic Publishers, Dordrecht, 57-67.

Marchese M. and Ezcurra de Grago I., 2006. Bentos como indicador de condiciones tróficas del sistema del Río Paraná Medio. In: Tundisi J.G., Matsumura-Tundisi T. and Galli, C.S. (eds.), Eutrofização na América do Sul, Instituto Internacional de Ecologia, São Carlos, 297-316.

Margalef R., 1994. The place of epicontinetal waters in global ecology. In: Margalef R. (ed.). Limnology now: a paradigm of planetary problems. Amsterdam, Elsevier Science, 1-8.

Martin P., 1996. Oligochaeta e Aphanoneura in ancient lakes: a review. Hydrobiologia, 334, 63-72. 
Martin P., Martens K. and Goddeeris B., 1999. Oligochaeta from the abyssal zone ofLake Baikal (Siberia, Russia). In: Healy B.M., Reynoldson T.B. and Coates K.A. (eds.), Aquatic Oligochaetes. Hydrobiologia, 406, 165-174.

Martinez-Anselmi E. and Prat N., 1984. Oligochaeta from profundal zones of Spanish reservoirs. Hydrobiologia, 115, 223-230.

Martins R.T., Silveira L.S., Alves R.G., 2011. Colonization by oligochaetes (Annelida: Clitellata) in decomposing leaves of Eichhornia azurea (SW.) Kunth (Pontederiaceae) in a neotropical lentic system. Ann. Limnol. - Int. J. Lim., 47, 339-346.

Matsumura-Tundisi T., Luzia A.P., Tundisi J.G., 2006. Estado trófico dos reservatórios em cascata do médio e baixo Tietê (SP) e manejo para o controle da eutrofização. In: Tundisi J.G., Matsumura-Tundisi T. and Galli C.S. (eds.), Eutrofização na América do Sul, Instituto Internacional de Ecologia, São Carlos, 141-160.

McCune B. and Mefford M.J., 1999. PC-ORD. Multivariate Analysis of Ecological Data, Version 3.15, Gleneden Beach, MJM Software, Oregon.

Menetrey N., Oertli B., Sartori M., Wagner A. and Lachavanne J.B., 2005. Eutrophication: are mayflies (Ephemeroptera) good bioindicators for ponds? Hydrobiologia, 597, 125-135.

Michaelsen W. 1900. Oligochaeta. Das Tierreich, 10. R. Friedländer und Sohn. Berlin, XXIX + 575 p.

Moretto Y., Higuti J. and Takeda A.M., 2003. Spatial variation of the benthic community in the Corumbá reservoir,Goiás, Brazil. Acta Sci., 25, 23-30.

Müller O.F. 1773-74. Vermium terrestrium et fluviatilium, II. Hafniae et Lipsiae (not seen, quoted from Sperber, 1948).

Oksanen J., Blanchet F.G., Kindt R., Legendre P., Minchin P.R., O'Hara R.B., Simpson G.L., Solymos P., Stevens M.H.H., Wagner H., 2011. VEGAN: Community Ecology Package. Available online at: http://cran.r-project.org/.

Pagioro T.A., Velho L.F.M., Lansac-Tôha F.A., Pereira D.G. and Nakamura A.K.S., 2005. Influência do grau de trofia sobre os padrões de abundância de bactérias e protozoários planctônicos em reservatórios do Estado do Paraná. In: Rodrigues L., Thomaz S.M., Agostinho A.A. and Gomes L.C. (eds.), Biocenoses em reservatórios: padrões espaciais e temporais, Rima, São Carlo, 47-56.

Peralta L., Escobar E., Alcocer J. and Lugo A., 2002. Oligochaetes from six tropical crater lakes in Central México: species composition, density and biomass. Hydrobiologia, 467, 109-116.

Peres-Neto P.R., Legendre P., Dray S. and Bocard D., 2006. Variation partitioning of species data matrices: estimation and comparison of fractions. Ecology, 87, 2614-2625.

Raposeiro P.M., Ramos J.C. and Costa A.C., 2009. First record of Branchiura sowerbyi Beddard, 1892 (Oligochaeta: Tubificidae) in Azores. Aquat. Invas., 4, 487-490.

R Core Team, (2011). R: A Language and Environment for Statistical Computing, R Foundation for Statistical Computing, Vienna, Austria. ISBN 3-900051-07-0, URL Available online at http://www.R-project.org/.

Real M. and Prat N., 1992. Factors influencing the distribution of chironomids and oligochaetes in profundal areas of Spanish reservoirs. Neth. J. Aquat. Ecol., 26, 405-410.

Righi G. and Varela M.E., 1983. Narapa bonettoi, gen. nov., sp. nov. (Oligochaeta, Narapidae, Fam. nov.) de agua doce da Argentina. Rev. Asoc. Cienc. Nat. Litoral 14, 7-15.
Rîsnoveanu G. and Vãdineanu A., 2003. Long term functional changes within the Oligochaeta communities within the Danube River Delta, Romania. Hydrobiologia, 506-509, 399-405.

Rocha O., Tavares K.S., Branco M.B., Pamplin P.A.Z., Espíndola E.L.G. and Marchese M., 2006. Padrões de biodiversidade em reservatórios e relações com o processo de eutrofização. In: Tundisi J.G., Matsumura-Tundisi T. and Galli C.S. (eds.), Eutrofização na América do Sul, Instituto Internacional de Ecologia, São Carlos, 353-372.

Rodrigues L., Fonseca I.A., Leandrini J.A., Felisberto S.A. and Silva E.L.V., 2005a. Distribuição espacial da biomassa perifítica em reservatórios e relação com o tipo de substrato. In: Rodrigues L., Thomaz S.M., Agostinho A.A. and Gomes L.C. (eds.), Biocenoses em reservatórios: padrões espaciais e temporais, Rima, São Carlos, 87-96.

Rodrigues L.C., Train S., Pivato B.M., Bovo V.M., Borges P.A.F. and Jati S., 2005b. Assembléias fitoplanctônicas de trinta reservatórios do Estado do Paraná. In: Rodrigues L., Thomaz S.M., Agostinho A.A. and Gomes L.C. (eds.), Biocenoses em reservatórios: padrões espaciais e temporais, Rima, São Carlos, 57-72.

Rossaro B., Boggero A., Lencioni A., Marziali L. and Solimini A., 2006. Tools for the development of a bentic quality index for Italian lakes. J. Limnol., 65, 41-51.

Saether O.A., 1979. Chironomid communities as water quality indicators. Holarctic Ecology, 2, 65-74.

Särkkä J., 1992. On the ecology of littoral Oligochaeta of an oligotrophic Finnish lake. Holarctic Ecol., 5, 396-404.

Schenková J., Komarék O. and Zahrádková S., 2001. Oligochaeta of the Morava and Odra River basin (Czech Republic): species distribution and community composition. Hydrobiologia, 463, 235-240.

Schenková J., Helesic J. and Jarkovský J., 2006. Seasonal dynamics of Bythonomus lemani and Bothrioneurum vejdovskyanun (Oligochaeta, Annelida) in relation to environmental variables. Biol. Bratislava, 61, 517-523.

Slepukhina T.D., 1984. Comparison of different methods of water quality evaluation by means of oligochaetes. In: Bonomi G. and Erséus C. (eds.), Aquatic Oligochaeta. Hydrobiologia, 115, 183-186.

Sporka F., 1996. Macrozoobenthos - permanent fauna. In: Krno I. (ed.), Limnology of the Turiec River Basin (West Carpathians, Slovakia). Biol. Bratislava, 51, 23-27.

Stat Soft Inc., 2005. Statistica (data analysis software system) version 7.1. Available online at http://www.statisoft.inc.

Stendera S.E.S. and Johnson R.K., 2005. Additive partitioning of aquatic invertebrate species diversity across multiple spatial scales. Freshw. Biol., 50, 1360-1375.

Suguio K., 1973. Introdução à sedimentologia, Edgard Blücher, São Paulo, 317 p.

Takahashi M.A., Higuti J., Bagatini Y.M., Zviejkovski I.P. and Velho L.F.M., 2008. Composition and biomass of larval chironomid (Insecta, Diptera) as potential indicator of trophic conditions in southern Brazil reservoirs. Acta Limnol. Bras., 20, 5-13.

Toledo A., Talarico M., Chinez S.J. and Agudo E.G., 1983. A aplicação de modelos simplificados para a avaliação do processo de eutrofização em lagos e reservatórios tropicais. In: Anais do $12^{\circ}$ Congresso Brasileiro de Engenharia Sanitária e Ambiental, Santa Catarina, 1-34.

Van Duinen G.A., Timm T., Smolders A.J.P., Brock A.M.T., Verberk W.C.E.P. and Esselink H., 2006. Differential 
response of aquatic oligochaete species to increased nutrient availability - a comparative study between Estonian and Dutch raised bogs. Hydrobiologia, 564, 143-155.

Verdonschot P.F.M., 1989. The role of oligochaetes in the management of waters. In: Kaster J. L. (ed.), Aquatic Oligochaete Biology. Hydrobiologia, 180, 213-227.

Verneaux V. and Aleya L., 1998. Bathymetric distributions of chironomid communities in ten French lakes: implications on lake classification. Arch. Hydrobiol., 142, 209228.
Weijters M.J., Janse J.H., Alkemade R. and Verhoeven J.T.A., 2009. Quantifying the effect of catchment land use and water nutrient concentrations on freshwater river and stream biodiversity. Aquat. Conserv. Mar. Freshw. Ecos., 19, 104-112.

Wentworth C.K., 1922. A scale of grade and class terms for clastic sediments. J. Geol., 30, 377-392.

Zimmerman G.M., Goetz H. and Mielke P.W., 1985. Use of an improved statistical method for group comparisons to study effects of prairie fire. Ecology, 66, 606-611. 


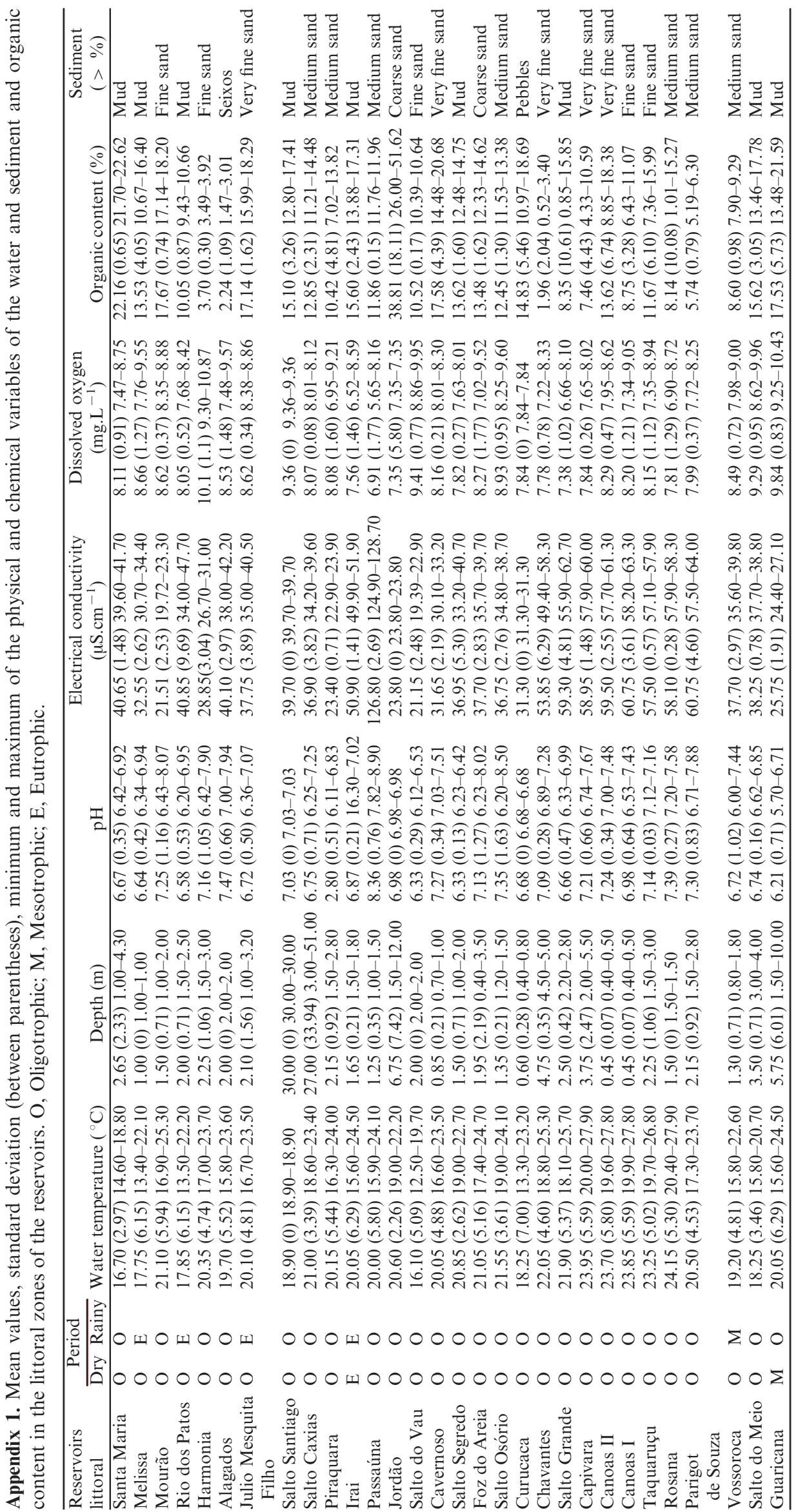




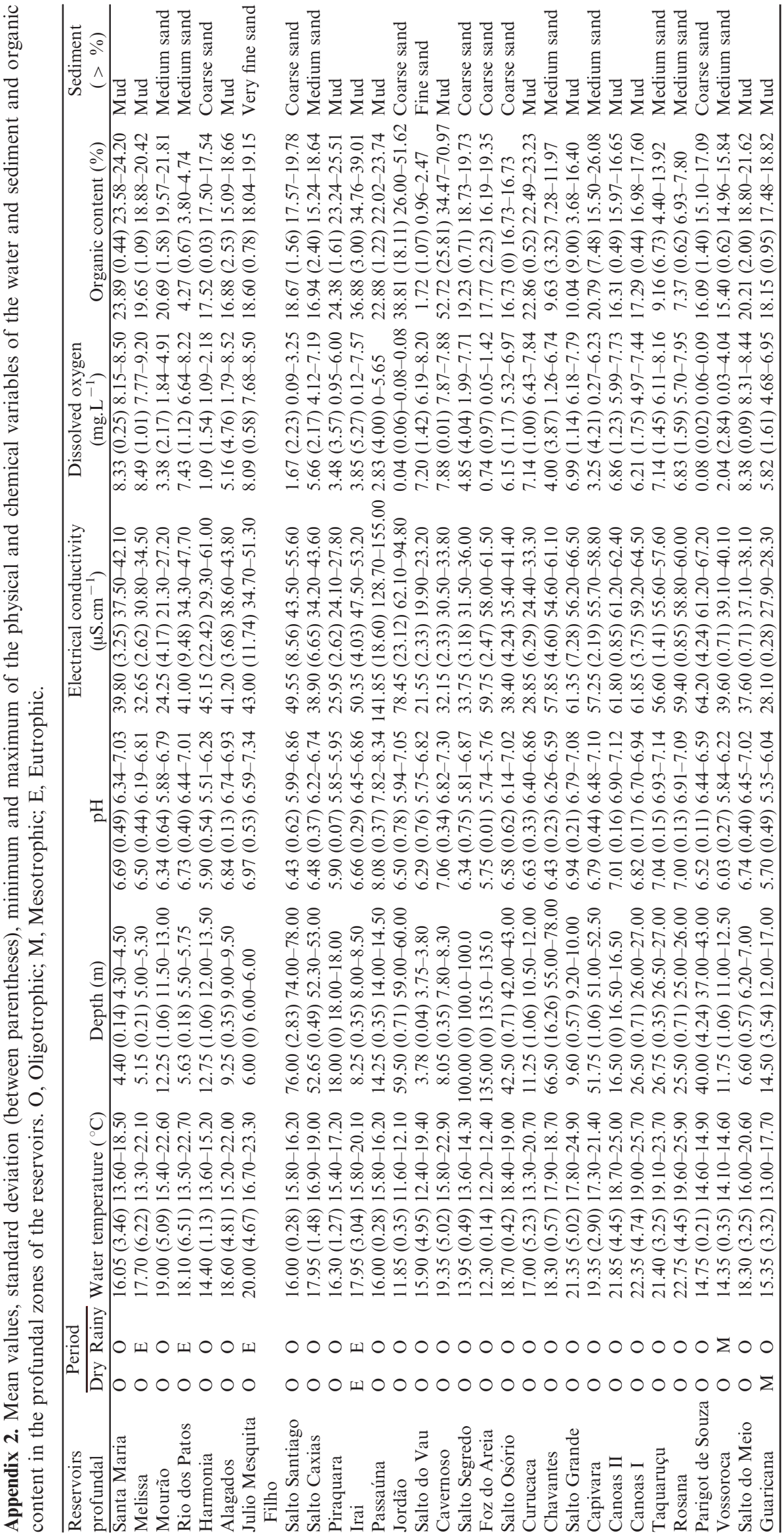

